\title{
Significance of drone technology for achievement of the United Nations sustainable development goals
}

\author{
Haula Kitonsa $\bowtie$, Sergey V. Kruglikov \\ Ural Federal University, Ekaterinburg, Russia; e-mail: kitsxauxkissule@gmail.com
}

\begin{abstract}
The drone technology, which originated in military applications, is now widely used for commercial, professional, industrial and private purposes. Applications of Unmanned Aerial Vehicles (UAVs), commonly known as drones, include different sectors of economy, for example, agriculture, transport, infrastructure, entertainment, and telecommunications. Not only are drones eco-friendly gadgets that allow to reduce the amount of carbon dioxide emissions, but they are also time- and cost-efficient. Thus, drones can prove to be a major force for good as they hold massive potential for being used to meet the sustainable development goals (SDGs) set by the United Nations Organization and adopted in 2015. Developing countries, for instance those of Sub-Saharan Africa, are facing famine, epidemic diseases, poverty and other challenges. All these problems can be addressed with the help of the drone technology. The main objective of this paper is to identify the sectors that are most likely to be influenced by the drone technology and to highlight the scenarios in which this technology can influence the achievement of the SDGs. One of the most promising spheres in this respect is the usage of drones as delivery vehicles in agriculture, e-commerce, and health care. Moreover, drones can be effective for monitoring and surveillance in international and domestic law enforcement, wildlife preservation and scientific research.
\end{abstract}

\section{KEYWORDS}

drone technology, unmanned aerial vehicles, sustainable development goals, United Nations, agricultural drones, drone applications, drone risks

\section{FOR CITATION}

Kitonsa, H., \& Kruglikov, S. V. (2018) Significance of drone technology for achievement of the United Nations sustainable development goals. R-economy, 4(3), 115-120. doi: 10.15826/recon.2018.4.3.016

\section{Значимость технологии дронов в достижении целей устойчивого развития ООН}

\author{
Х. Китонса $\square$, С. В. Кругликов \\ Уральский федеральный университет, Екатеринбург, Россия; e-mail: kitsxauxkissule@gmail.com
}

\section{PEЗЮME}

Технология беспилотных летательных аппаратов, созданная военными, в настоящее время широко используется в коммерческих, профессиональных, промышленных и частных целях. Беспилотные летательные аппараты (БПЛА), широко известные как «дроны», используются в различных секторах экономики, например, сельском хозяйстве, транспорте, инфраструктуре, развлечениях и телекоммуникациях. Дроны не только экологичны и позволяют сократить количество выбросов углекислого газа, но они также экономичны в терминах времени и финансовых затрат. Таким образом, беспилотные летательные аппараты могут оказаться серьезной силой, поскольку они обладают огромным потенциалом для использования в целях достижения целей устойчивого развития (SDG), установленных Организацией Объединенных Наций и принятых в 2015 г. Развивающиеся страны, например, страны, расположенные к югу от Сахары, сталкиваются с голодом, эпидемическими заболеваниями, нищетой и другими проблемами. Все эти проблемы можно решить с помощью технологии беспилотных летательных аппаратов. Основная цель этой статьи - выявить сектора, на которые, скорее всего, повлияет технология беспилотных летательных аппаратов, и выделить сценарии, в которых эта технология может повлиять на достижение целей устойчивого развития. Одной из наиболее перспективных сфер в этом отношении является использование дронов в качестве средств доставки в сельском хозяйстве, электронной торговле и здравоохранении. Более того, беспилотные летательные аппараты могут быть эффективными для мониторинга и наблюдения в международных и внутренних правоохранительных органах, охране дикой природы и научных исследованиях.

\section{КЛЮЧЕВЫЕ СЛОВА}

беспилотная техника, беспилотные летательные аппараты, цели устойчивого развития, Организация Объединенных Наций, сельскохозяйственные беспилотные летательные аппараты, применение беспилотных летательных аппаратов

\section{ДЛЯ ЦИТИРОВАНИЯ}

Kitonsa, H., \& Kruglikov, S. V. (2018) Significance of drone technology for achievement of the United Nations sustainable development goals.

R-economy, 4(3), 115-120. doi: 10.15826/recon.2018.4.3.016 


\section{Introduction}

Developing countries, in particular those located in Sub-Saharan Africa, have for a long time been facing severe famine, epidemic diseases, poverty and malnutrition issues $[1 ; 2]$. Social and economic development in Africa is affected by high mortality rate $[3 ; 4]$ and poor health which are a result of malnutrition. In addition to environmental issues, the rapidly growing human population leads to an increased poverty rate, which still remains the highest in the world as of 2012 [5].

So far approaches to combating hunger and malnutrition have mostly focused on increased food production and food security paying less attention to the water scarcity problem. Water has a vital role in ensuring food security as $70 \%$ of the population [6] in Sub-Saharan Africa depends on agriculture for survival and more than $90 \%$ of this agriculture is sustained by direct rain. Therefore, agriculture still remains the major response to addressing hunger and malnutrition.

In 2015, the international community adopted seventeen global goals for sustainable development (SDGs) to improve people's lives by 2030. These SDGs comprise 169 targets [7-9] measured on local, national, regional and global levels and across various sectors. The SDGs place greater demands on the scientific community to address climate change, renewable energy, food, health and water provision. Great emphasis has been put on the need for social inclusion, economic development, and environmental sustainability and on outreach for marginalized groups [10]. "Sustainable development is the development that meets the needs of the present without compromising the ability of the future generations to meet their own needs" [11]. This study aims to provide a brief overview of the role that drone technology may play in meeting the SDGs.

\section{Potential Usage of Drones to Achieve SDGs}

Recently, there has been a rapid growth in the popularity of Unmanned Aerial Vehicles (UAVs) commonly known as drones on the civil market. Although originally drones were used in the military sector, they are now widely used both in civil and commercial domains for parcel deliveries and other purposes [12]. Regardless of the fact that drone technology is still at its infant stage in terms of commercial usage, its current and speculated commercial applications have already shown the potential to dramatically alter several industries in terms of reducing on workload and general costs of production, time saving, increase on work efficiency and productivity and also bridge gap between urban and rural areas. Various stakeholders and actors, including governmental bodies, such as law enforcement agencies, commercial firms, scientific institutions [13] and private individuals, have realized the benefits inherent in the use of drones. Hence, in the coming years, the adoption of drone technology will undoubtedly turn into a great trend as more and more industries are embracing the technology (Figure).

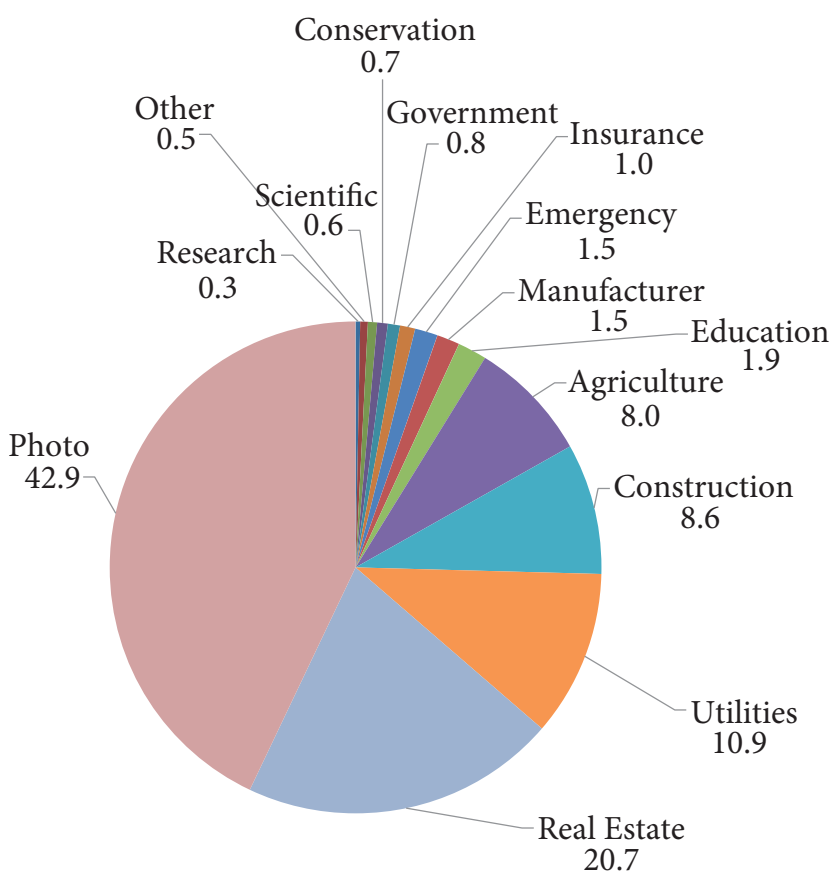

Top industries influenced by the drone technology in 2015

Source: FAA, The Verge Drone Project, 2015

Let us now consider some of the SDGs put forward by the United Nations and the potential usage of the drone technology to meet these goals. One of such goals is to end hunger, achieve food security and improved nutrition and promote sustainable agriculture. Drone technology can be used in agricultural sector [14] in a number of ways, for example, to survey farm fields [15], to ensure product delivery [16] and to spray pesticides. Rather than spraying the entire field, the pesticide can be delivered to the right spot, only in the quantity needed, which means reduction in pesticides used, reduction in collateral damage to wildlife and also enhanced cost-efficiency [17]. The case of Japan provides a good 
illustration for such applications of the drone technology. Since the 1970s, this country has accumulated significant experience in this sphere. Nearly 2,000 UAVs are being used in Japan today for agricultural spraying and planting operations [18]. Furthermore, drones can connect farmers to markets and thus ensure that everyone has access to affordable nutritious food. Chinese retail giant JD.com uses drones for e-commerce shipments to remote areas as well as to small towns or cities. It also transports farm equipment, fertilizers and seeds.

Apart from the agricultural usage of drones, they can also be successfully employed as delivery vehicles as they are able to traverse difficult landscapes and reach remote areas [19]. For instance, company Zipline in Rwanda has been delivering medical supplies to rural areas since 2016 by using drones and dropping off blood parcels attached to parachutes [29]. Over 50 deliveries are made daily, thus saving thousands lives. This experience has already drawn attention of other countries such as Canada and Tanzania seeking to adopt this practice [21]. Moreover, drones can be employed in emergency situations as ambulances to provide first aid to patients prior to being admitted to the hospital. In remote areas, medical services often take long to respond and to reach a patient with cardiac arrest or similar conditions [22]. In case of natural disasters, such as mudslides, earthquake, floods, explosions and wild fires, immediate and swift medical attention is needed as lives some survivors depends on it. So drones can be used to quickly scan the area and locate the victims with the help of on-board cameras providing real-time data [23].

Another promising sphere for drone usage is scientific research: as drones can withstand extreme conditions and are expendable, which makes them perfect research of diseases, pollution levels in regions with extreme weather conditions, radioactive areas and so on [24].

Another important goal set forth by the UN is to ensure sustainable economic growth, full and productive employment and decent work for all. In this respect, the drone technology promises diverse and attractive possibilities and is bound to reshape a number of business sectors whilst creating enormous employment opportunities [25]. Among other things, drones have the potential to restructure the delivery market and open new business opportunities for small businesses such as local stores, pharmacies, fast-foods as well as large international and national businesses and government entities.

Drones also hold a lot of potential for the development of tourism. Video cameras are attached to drones that can record and capture picturesque aerial views of different places such as historical and natural sites. These aerial views and videos can be used to promote tourism [26], once they are shared or uploaded to any social network. Moreover, drones can be used for virtual tourism: a tourist may be sitting at home and receiving live videos on the phone or computer in $3 \mathrm{D}$ format from a drone flying over places of interest [27].

One more significant advantage of drones is that they are a safe and environmentally sound technology. Deploying drones for last-mile delivery reduces the amount of carbon dioxide emissions which would have been produced if the goods were delivered by other means of transport [28]. Moreover, drones have proven to be an effective alternative to fireworks, which can spark off wildfires. Therefore, drones were used for this purpose in California, Colorado, and Arizona in the USA, which suffered from wildfires. Thus, these states decided to use a fleet of 500 Intel star drones to dance to patriotic music on $4^{\text {th }}$ July celebrations.

Gas sensors and cameras can be mounted on drones and thus flown over volcanic areas, seas, forests among other places to monitor the situation. Drones can detect natural disasters prior to their occurrence, thus alerting the citizens of a particular area and enabling them to evacuate [29].

Another sphere in which drones can play an important role is surveillance of wildlife: for instance, Kruger National park in South Africa is known as the world's number one poaching site for rhino [30]. Having a fleet of drones with cameras providing real time data and hovering all over the park will help the authorities to fight poaching.

Drones have proven instrumental in the utilities and energy sector to perform long-range aerial inspections of energy infrastructure, including pipelines and electric wires that can run for thousands of miles. Power line maintenance and repairs can be very expensive and dangerous for workers. Electric companies can use drones to access damaged power lines or structures and transmit pictures and information that can facilitate working on solutions more quickly, hence ensuring the achievement of sustainable development. 
The UN have also set the target to significantly increase access to information and communications technology and to provide universal and affordable access to the Internet in the least developed countries by 2020. Mark Zuckerberg has recently announced his plans to provide Internet access to remote parts of the world by launching an initiative that involves the usage of solar-powered drones, capable of staying airborne for years and acting as movable wireless access points [31].

The UN's SDG to ensure peace, justice and strong institutions can be met through efficient law enforcement, for which drones have proven to be indispensable. Drones can be deployed to pursue suspects in vast, open areas and areas that are inaccessible or difficult to access for human officers [32]. Moreover, drones can be an effective technological solution for border patrol as they are capable of scanning wide areas, see through walls and track individual movements from the sky. Thus, drones can be used to monitor the movements of illegal migrants.

\section{Risks of Using Drones}

Despite the obvious advantages of drones described above, the potential misuse of the drone technology grows proportionally to its popularity. Drone operation can pose a threat to both public and national security, which explains why most legal authorities seem to be in two minds about making fully legalizing this technology. There is ongoing communication between the different regulating bodies in different countries such as the Federal Aviation Administration (FAA), the European Aviation Safety Agency (EASA), Transport Canada and Civil Aviation Authority (CAA), and others. It should be noted here that most of the countries have used the FAA's guidelines for their drone regulations. To balance safety and innovation, international cooperation is required to enable countries work towards the common goal and ensure the maximum safety of drone usage. Drone regulations set by the European Aviation Safety Agency [33] were adopted by 27 member states (Austria, Belgium, Bulgaria, Cyprus, Czech Republic, Denmark, Estonia, Finland, France, Germany, Greece, Hungary, Ireland, Italy, Latvia, Lithuania, Luxembourg, Malta, Netherlands, Poland, Portugal, Romania, Slovak Republic, Slovenia, Spain, Sweden, and the UK).

\section{Conclusion}

It is evident that drones are going to make a great contribution to the achievement of the SDGs. Drone technology not only has a promising robust influence in the agricultural sector, but in a number of other sectors. Despite all the above-described advantages offered by the development of the drone technology, legal regulations in some countries, Russia in particular, impede efficient use of drones. Full legalization of drone operations is required in all sectors of economy. Countries, such as China, Rwanda, Japan and the USA, have taken steps in this direction. Therefore, it can be concluded that it is only a matter of time until drones are fully legalized for civil and commercial use. In the context of SSA, the drone technology might turn out to be the ultimate path to finally reducing or completely eliminating hunger, poverty and malnutrition problems.

In future studies, we intend to analyze and compare practices of drone operation in SSA and in Russian regions, for example, in the Urals and in Yakutsk, in order to show the potential for the achievement of SDGs on these territories.

\section{References}

1. Pinstrup-Andersen, P., Rahmanian, M., Allahoury. A., et at. (2015). Water for Food Security and Nutrition: A Report by the High Level Panel of Experts on Food Security and Nutrition of the Committee on World Food Security. FAO: Rome, Italy. Retrieved from http://www.fao.org/3/aav045e.pdf

2. Mabhaudhi, T., Chibarabada, T., \& Modi, A. (2016). Water-Food-Nutrition-Health Nexus: Linking Water to Improving Food, Nutrition and Health in Sub-Saharan Africa. International Journal of Environmental Research and Public Health, 13(1), 107. doi: 10.3390/ijerph13010107

3. Crosby, L., Jayasinghe, D., McNair, D. (2013). Save the Children. Food for Thought: Tackling Child Malnutrition to Unlock Potential and Boost Prosperity. London, UK: Save the Children. Retrieved from https://resourcecentre.savethechildren.net/node/7414/pdf/food for thought uk.pdf

4. Food and Agriculture Organization. (1996). The Rome Declaration on World Foods Security. Population and Development Review, 22, 14-17. 
5. Beegle, K., Christiaensen, L., Dabalen, A., \& Gaddis, I. (2016). Poverty in a Rising Africa. The World Bank. Retrieved from http://hdl.handle.net/10986/22575

6. Livingston, G., Schonberger, S., \& Sara, D. (2011). Sub-Saharan Africa: The State of Smallholders in Agriculture. Rome: Via Paolo Di Dono. Retrieved from https://pdfs.semanticscholar.org/ f2cb/d3f72cb333c1cc6fd3eba6d5bc8bb8c89469.pdf

7. Lu, Y., Nakicenovic, N., Visbeck, M., \& Stevance, A. S. (2015). Five Priorities for the UN Sustainable Development Goals. Nature, 520(7548), 432-433. doi: 10.1038/520432a

8. Sachs, J. D. (2012). From Millennium Development Goals to Sustainable Development Goals. The Lancet, 379(9832), 2206-2211. doi: 10.1016/S0140-6736(12)60685-0

9. Mougeot, L. J. (2006). Growing Better Cities: Urban Agriculture for Sustainable Development. IDRC. Retrieved from https://www.idrc.ca/sites/default/files/openebooks/226-0/index.html

10. Tebbutt, E., Brodmann, R., Borg, J., MacLachlan, M., Khasnabis, C., \& Horvath, R. (2016). Assistive Products and the Sustainable Development Goals (SDGs). Globalization and Health, 12(1), 79. doi: 10.1186/s12992-016-0220-6

11. Brundtland, G. H. (1985). World Commission on Environment and Development. Environmental Policy and Law, 14(1), 26-30.

12. Marin, L. (2016). The Humanitarian Drone and the Borders: Unveiling the Rationales Underlying the Deployment of Drones in Border Surveillance. In: The Future of Drone Use (pp. 115132). TMC Asser Press, The Hague. doi: $10.1007 / 978-94-6265-132-6 \_6$

13. Stöcker, C., Bennett, R., Nex, F., Gerke, M., \& Zevenbergen, J. (2017). Review of the Current State of UAV regulations. Remote Sensing, 9(5), 459. doi: 10.3390/rs9050459

14. Tripicchio, P., Satler, M., Dabisias, G., Ruffaldi, E., \& Avizzano, C. A. (2015). Towards Smart Farming and Sustainable Agriculture with Drones. In 2015 International Conference on Intelligent Environments, 15-17 July 2015, Prague, Czech Republic (pp. 140-143). IEEE. doi: 10.1109/IE.2015.29

15. Krishna, K. R. (2016). Push Button Agriculture: Robotics, Drones, Satellite-Guided Soil and Crop Management. Apple Academic Press.

16. Bamburry, D. (2015). Drones: Designed for Product Delivery. Design Management Review, 26(1), 40-48.

17. King, A. (2017). Technology: The Future of Agriculture. Nature, 544(7651), 21-23. doi: $\underline{10.1038 / 544 \text { S21a }}$

18. DeGarmo, M., Nelson, G. (2004). Prospective Unmanned Aerial Vehicle Operations in the Future National Airspace System. In AIAA $4^{\text {th }}$ Aviation Technology, Integration and Operations (ATIO) Forum. Chicago: Illinois. doi: $\underline{10.2514 / 6.2004-6243}$

19. Haidari, L. A., Brown, S. T., Ferguson, M., Bancroft, E., Spiker, M., Wilcox, A., Ambikapathi, R., Sampath, V., Connor, D. L., \& Lee, B. Y. (2016). The Economic and Operational Value of Using Drones to Transport Vaccines. Vaccine, 34(34), 4062-4067. doi: 10.1016/j.vaccine.2016.06.022

20. Ackerman, E., \& Strickland, E. (2018). Medical Delivery Drones Take Flight in East Africa. IEEE Spectrum, 55(1), 34-35. doi: 10.1109/MSPEC.2018.8241731

21. Glauser, W. (2018). Blood-Delivering Drones Saving Lives in Africa and Maybe Soon in Canada. CMAJ, 190(3), E88-E89. doi: 10.1503/cmaj.109-5541

22. Van de Voorde, P., Gautama, S., Momont, A., Ionescu, C. M., De Paepe, P., Fraeyman, N. (2017). The Drone Ambulance [A-UAS]: Golden Bullet or Just a Blank? Resuscitation, 116, 46-48. doi: 10.1016/j.resuscitation.2017.04.037

23. Câmara, D. (2014). Cavalry to the Rescue: Drones Fleet to Help Rescuers Operations over Disasters Scenarios. In 2014 IEEE Conference on Antenna Measurements \& Applications (CAMA), 16-19 Nov. 2014, Antibes Juan-les-Pins, France. IEEE. doi: 10.1109/cama.2014.7003421

24. Hattenberger, G., Bronz, M., Gorraz, M. (2014). Using the Paparazzi UAV System for Scientific Research. In IMAV 2014: Proceedings of the International Micro Air Vehicle Conference and Competition 2014, 12-15 Aug. 2014 (pp. 247-252). Delft: Delft University of Technology. doi: $\underline{10.4233 /}$ uuid:b38fbdb7-e6bd-440d-93be-f7dd1457be60

25. Custers, B. (Ed.) (2016). Future of Drone Use: Opportunities and Threats from Ethical and Legal Perspectives. TMC Asser Press. doi: 10.1007/978-94-6265-132-6 
26. Alexis, P. (2017). R-Tourism: Introducing the Potential Impact of Robotics and Service Automation in Tourism. Ovidius University Annals, Series Economic Sciences, 17(1), 211-216. Retrieved from $\underline{\mathrm{http}: / / \text { stec.univ-ovidius.ro/html/anale/RO/2017/Section-III/16.pdf }}$

27. Mirk, D., \& Hlavacs, H. (2014). Using Drones for Virtual Tourism. In: INTETAIN 2014: Proceedings of the $6^{\text {th }}$ International Conference on Intelligent Technologies for Interactive Entertainment, Chicago, IL, USA, July 9-11, 2014. (pp. 144-147). Springer, Cham. doi: 10.1007/9783-319-08189-2 21

28. Goodchild, A., \& Toy, J. (2018). Delivery by Drone: An Evaluation of Unmanned Aerial Vehicle Technology in Reducing CO2 Emissions in the Delivery Service Industry. Transportation Research Part D: Transport and Environment, 61, 58-67. doi: 10.1016/j.trd.2017.02.017

29. Dunnington, L., \& Nakagawa, M. (2017). Fast and Safe Gas Detection from Underground Coal Fire by Drone Fly Over. Environmental Pollution, 229, 139-145. doi: 10.1016/j.envpol.2017.05.063

30. Lunstrum, E. (2014). Green Militarization: Anti-Poaching Efforts and the Spatial Contours of Kruger National Park. Annals of the Association of American Geographers, 104(4), 816-832. doi: $\underline{10.1080 / 00045608.2014 .912545}$

31. Maharana, S. (2017). Commercial Drones. In Proceedings of IRF International Conference, Mumbai, India.

32. Straub, J. (2014). Unmanned Aerial Systems: Consideration of the Use of Force for Law Enforcement Applications. Technology in Society, 39, 100-109. doi: 10.1016/j.techsoc.2013.12.004

33. Cracknell, A. P. (2017). UAVs: Regulations and Law Enforcement. International Journal of Remote Sensing, 38(8-10), 3054-3067. doi: $\underline{10.1080 / 01431161.2017 .1302115}$

\section{Information about the authors}

Haula Kitonsa - Researcher, Graduate School of Economics and Management, Ural Federal University (19 Mira St., 620002 Ekaterinburg, Russia); e-mail: kitsxauxkissule@gmail.com.

Sergey V. Kruglikov - Head of Academic Department of Controlled Systems, Graduate School of Economics and Management, Ural Federal University (19 Mira St., 620002 Ekaterinburg, Russia); e-mail: svk@imm.uran.ru. 